\title{
Mapping Surface Parameters for Mesoscale Modeling in Forested and Deforested Southwestern Amazonia
}

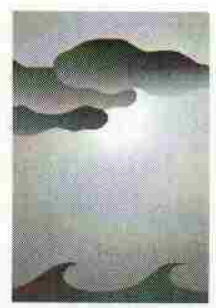

\author{
Jean-Christophe Calvet, ${ }^{*}$ Regina Santos-Alvalá,+ Geneviève Jaubert,* \\ Christine Delire, ${ }^{*}$ Carlos Nobre, ${ }^{+}$Ivan Wright," and Joël Noilhan*
}

\begin{abstract}
Surface parameter digital maps of vegetation, soil, and relief are obtained over Rondônia, Brazil, covering the $5^{\circ} \times$ $5^{\circ}$ region $8^{\circ}-13^{\circ} \mathrm{S}, 65^{\circ}-60^{\circ} \mathrm{W}$. Numerical maps of the natural landscape structure have been achieved by digitizing existing 1:1 000000 paper maps. Satellite data give information about the most recent modifications of the surface due to human activities. This mapping work is the first step of a mesoscale meteorological modeling program.
\end{abstract}

\section{Introduction}

The widespread transformation of natural forests into agricultural landscapes may induce regional or global changes in the biosphere-atmosphere interactions. There is increasing concern about the extent to which the current man-made change of the regional or global climate can be realistically evaluated. In recent years, several field campaigns have been carried out to obtain measurements of the energy and water budgets of both tropical rainforest and deforested areas in the Amazon basin. For example, the ABRACOS (Anglo-Brazilian Amazonian Climate Observation Study) (Gash et al. 1996) project set up a series of micrometeorological stations in various places of the Amazon basin from 1990 to 1993. These data can be used in meteorological models to help understand how Amazonian deforestation might change the climate.

\footnotetext{
*Météo-France/Centre National de Recherches Meteorologiques, Toulouse, France.

+Instituto Nacional de Pesquisas Espaciais, São José dos Campos, Brazil.

"Institute of Hydrology, Wallingford, United Kingdom. Corresponding author address: Jean-Christophe Calvet, MétéoFrance/CNRM, 42, Avenue G. Coriolis, 31057 Toulouse Cedex 1, France.

E-mail: calvet@meteo.fr

In final form 26 August 1996.

(C)1997 American Meteorological Society
}

In meteorological models, the simulation of the surface soil-vegetation-atmosphere exchanges is made by simple schemes (Sellers et al. 1986; Dickinson et al. 1986; Wetzel and Chang 1987; Noilhan and Planton 1989). Such models of surface processes can be used to predict the effects of largescale forest clearing on climate (e.g., Dickinson and Henderson-Sellers 1988; Nobre et al. 1991; Lean and Rowntree 1993; Polcher and Laval 1994; Manzi and Planton 1994; Rocha et al. 1996). They can also be employed at smaller scales for short-term weather predictions or for understanding the main processes controlling the mesoscale meteorology. Adequate treatment of surface properties such as soil moisture and vegetation characteristics is essential for accurate simulation of planetary boundary layer development and mesoscale circulations generated by land surface inhomogeneities, for example, forested and deforested areas (Mahfouf et al. 1987; Noilhan et al. 1991). In general, the surface schemes used for meteorological modeling require structure parameters of the surface: soil depth and soil texture, vegetation height (associated with the aerodynamic roughness of the surface), albedo, leaf area index, coverage, and the rainfall interception reservoir. The vegetation stomatal resistance properties are usually simulated by simple submodels. Some parameters of the canopy resistance models can be calibrated by inverting the surface scheme and comparing the resistances with those derived from in situ micrometeorological measurements of transpiration. At the mesoscale, an accurate esti- 
mation of the relief must be available. Its accuracy and spatial resolution must be compatible with the prescribed resolution of the model mesoscale grid.

In this work, several research teams have combined their efforts in order to create a suitable set of surface parameter maps for mesoscale modeling (relief-soilvegetation) over Rondônia, in a $5^{\circ} \times 5^{\circ}$ region $\left(8^{\circ}-\right.$ $13^{\circ} \mathrm{S}, 65^{\circ}-60^{\circ} \mathrm{W}$ ) presented in Fig. 1 . These maps will be used to perform meteorological mesoscale simulations within the framework of RBLE-3 (Rondônia Boundary Layer Experiment; Fisch 1995), which consisted of surface and radiosounding measurements in a forest (the Jaru Reserve Forest) and a pasture area $\left(61^{\circ} 50^{\prime} \mathrm{W}, 10^{\circ} 01^{\prime} \mathrm{S}\right.$ and $62^{\circ} 22^{\prime} \mathrm{W}, 10^{\circ} 45^{\prime} \mathrm{S}$, respectively) near Ji-Paraná $\left(61^{\circ} 50^{\prime} \mathrm{W}, 10^{\circ} 50^{\prime} \mathrm{S}\right)$ during August 1994. Rondônia is one of the Brazilian regions of the Amazon basin where forest clearing has been most extensive. The deforestation has been organized along parallel strips, and in general, the deforested areas consist of grasslands used for cattle grazing. The series of radiosoundings recorded simultaneously over forest and grassland during RBLE-3 present very distinct features. They indicate that the observed structure of the atmospheric boundary layer over the two surfaces is significantly different (Fisch 1995). Furthermore, Cutrim et al. (1995) have shown that deforestation in Rondônia may increase the frequency of shallow cumulus clouds during the dry season, based on satellite data of August 1988.

Whether these differences are due to the differences in the surface vegetation cover or to other effects (soil, relief, higher regional roughness length caused by the particular deforestation strip-patterns of this region) can only be investigated by performing 3D simulations with a mesoscale meteorological model, based

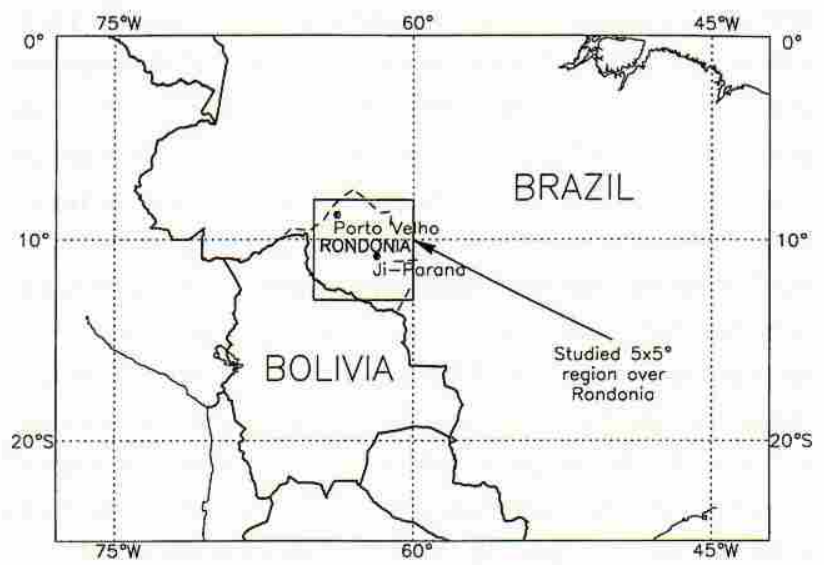

FIG. 1 . The studied $5^{\circ} \times 5^{\circ}$ region $\left(8^{\circ}-13^{\circ} \mathrm{S}, 65^{\circ}-60^{\circ} \mathrm{W}\right)$ in Brazil. on accurate maps of the surface parameters, deforestation, and relief.

\section{Data}

The employed geographical information consisted of both existing paper maps (for the natural landscape structures) and satellite data (for current alterations).

\section{a. Printed maps and documentation}

Natural vegetation and soil maps over Rondônia at the 1:1000 000 scale have been obtained from the RADAMBRASIL project $(1978,1979)$. Together with the printed color maps, very detailed notes are also available (RADAMBRASIL 1978, 1979). The corresponding topography maps, at the same scale, are from the Instituto Brasileiro de Geographica e Estatistica (IBGE 1979). These maps consist of the Porto Velho and Guaporé sheets, $\left(60^{\circ}-66^{\circ} \mathrm{W} ; 8^{\circ}-12^{\circ} \mathrm{S}\right.$; and $12^{\circ}-$ $16^{\circ} \mathrm{S}$, respectively). The southern natural limit of this area is formed by the Guaporé River, which separates Brazil (Rondônia state) from the Bolivian Republic.

The soil and vegetation maps of RADAMBRASIL $(1978,1979)$ combine information from radar images, airborne photographs, and many field studies as basic mapping tools. In particular, measurements of soil properties, such as texture (clay, sand, silt proportions) are given in the technical notes for various profiles over all the area. For vegetation, quantitative observations of the canopy height can be found in the Guaporé map note. Information about the vegetation species making up the vegetation classes are also given.

\section{b. Satellite data}

In this study, both low-resolution (Meteosat) and high-resolution (Landsat) satellite data are employed for spatial classification. The numerical counts are employed directly without atmospheric corrections.

\section{1) Meteosat}

Meteosat $-75^{\circ} \mathrm{W}$ data in full spatial $(\sim 5 \mathrm{~km})$ and temporal $\left(30^{\prime}\right)$ resolution during RBLE-3 (1125 August 1994) were provided by A. O. Manzi (1994, personal communication). They include both visible and infrared channels.

\section{2) LANDSAT-TM}

High-resolution satellite data are needed to obtain accurate deforestation maps. Seventeen Landsat-TM 
full-resolution $(30 \mathrm{~m})$ images (channels 1, 2, 3, 4, 5, and 7) from 1993 and 1994 were provided by INPE (Instituto Nacional de Pesquisas Espaciais, Brazil). They cover the entire $5^{\circ} \times 5^{\circ}$ studied area. The scenes have been geometrically corrected and put into a latitude-longitude coordinate system.

\section{Mapping process}

The 1:1 000000 maps of natural vegetation, soil, and surface relief were digitized over the $5^{\circ} \times 5^{\circ}$ region $\left(65^{\circ}-60^{\circ} \mathrm{W}, 8^{\circ}-13^{\circ} \mathrm{S}\right)$. A digital elevation model and a surface-type classification have been achieved by digitizing the contour lines of altitude above sea level and of the RADAMBRASIL surface classification, respectively. The rasterizing process was performed by using the GRASS software (1995).

\section{a. Natural vegetation}

For natural vegetation mapping, airborne radar images and in situ field observations were gathered by the RADAMBRASIL project. Many landscape units are described in both the Porto Velho and Guaporé maps. Because of northsouth ecological gradients, the vegetation classes vary from one map to another. The Porto Velho area is separated into four different ecological regions, 1) savannah, 2) pioneer formations, 3) closed, and 4) open rainforest, along with the areas of ecological tension and anthropic action. The Guaporé map includes another main ecological class, 5) tropical semidecidual seasonal forest. These main vegetation units are further divided and described as ecological subregions. For example, Fig. 2 shows section diagrams of the main classes of savannah and open rainforest. The subregions separate different canopy organizations (e.g., the proportion of grass, bushes, and trees in the savannah main class), often associated with the relief structure. Also, in the

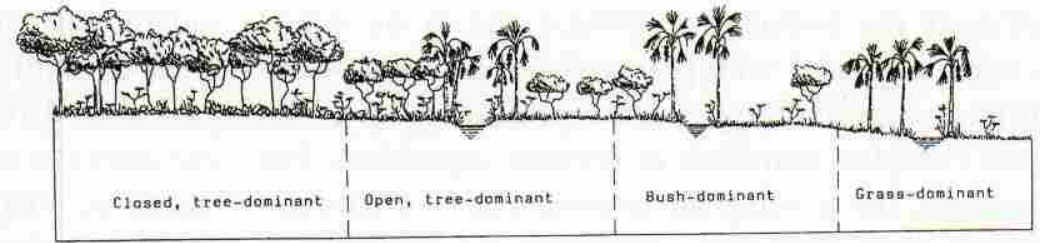

SAVANNAH

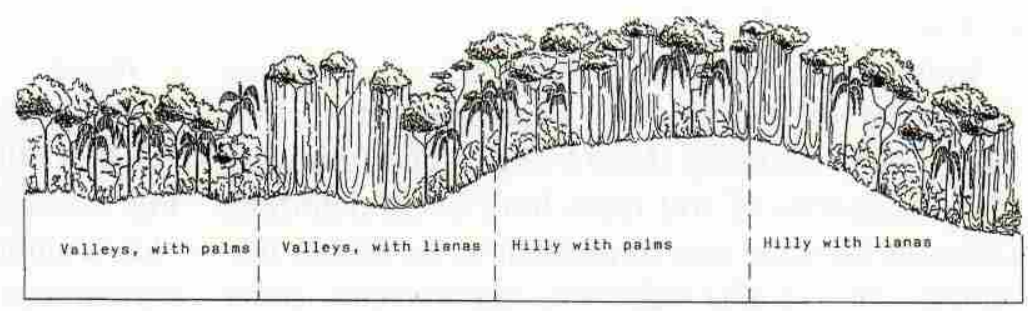

OPEN RAINFOREST

FIG. 2. Section diagrams of two natural vegetation main types: savannah and open rainforest [reproduced from RADAMBRASIL (1979)].

Guaporé map, the ecological subclasses of a given ecological region often differ from the subclasses of the Porto Velho map.

The natural vegetation rasterized image is shown in Fig. 3. Over the area covered by the two maps, a total of 91 subclasses are described. However, for clarity, Fig. 3 presents only the 13 most representative vegetation main classes in the studied $5^{\circ} \times 5^{\circ}$ region.

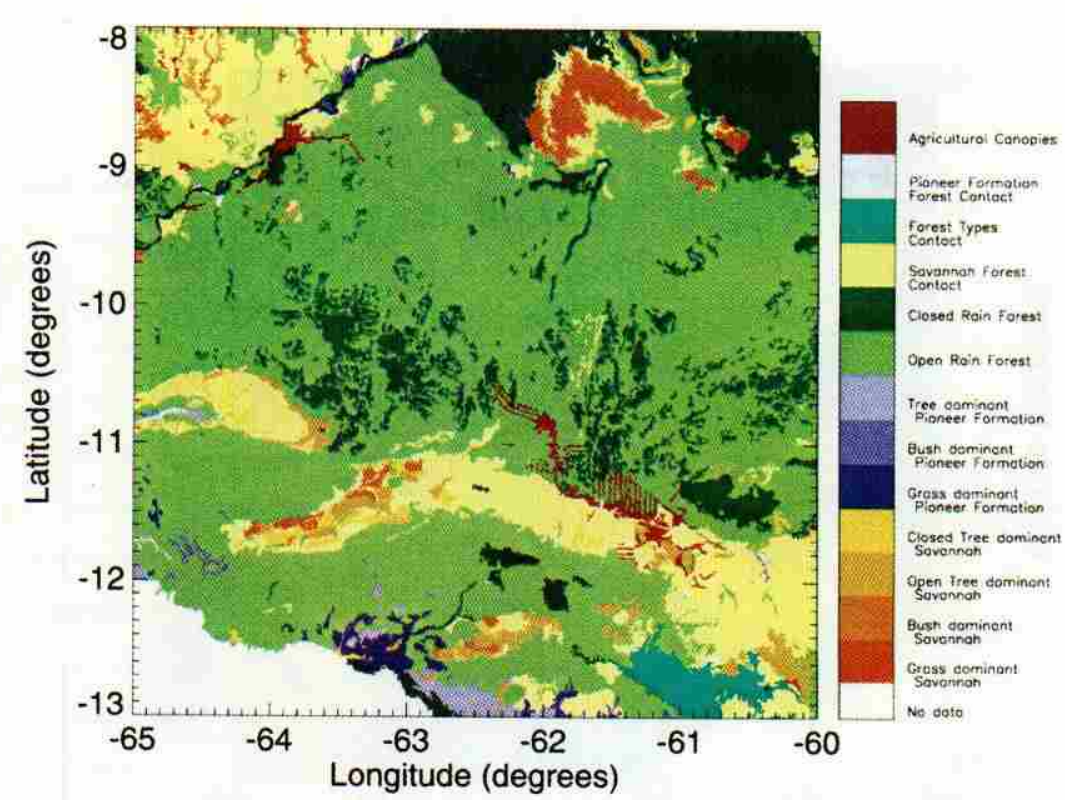

Fig. 3. Natural vegetation main classes for the $5^{\circ} \times 5^{\circ}$ region covering Rondônia $\left(8^{\circ}-13^{\circ} \mathrm{S}, 65^{\circ}-60^{\circ} \mathrm{W}\right)$. This $600 \times 600$ digital map is derived from the $1: 1000000$ RADAMBRASIL maps of Porto Velho and Guaporé (RADAMBRASIL 1978, 1979). 
Although the dominant vegetation unit in the region is open rainforest with palms, there are many other different vegetation types and significant areas of the more complex transition or contact vegetation. For example, the ecological tension class savannahforest contact constitutes a major natural landscape in a east-west strip to the south of Ji-Paraná $\left(61^{\circ} 50^{\prime} \mathrm{W}\right.$, $\left.10^{\circ} 50^{\prime} \mathrm{S}\right)$.

\section{b. Soil}

In the RADAMBRASIL maps, the soil classification is derived from the U.S. Department of Agriculture (USDA) taxonomy (USDA 1970). The following main categories of soil types have been identified. Lithosols (or lithic oxic troporthent in the USDA taxonomy), alluvial allic soils, (allic tropofluvent), quartz sands (allic quartzipsamment and spodic psammaquent), latosols (allic haplorthox and allic acrorthox), podzols [oxic (ultric) tropudalf, (allic) orthoxic (distropeptic) tropudult, allic plinthic paleudult], laterites (allic superic plinthaquox, allic oxic plinthaquult), cambisols (aquic eutropept and udoxic dystropept), gleyzed soils (allic tropaquept), "terras roxas" [oxic (ultric) tropudalf, rhodic paleudult], and rocky outcrops. The soil classes are defined according to physical criteria such as the soil-forming processes (geology, topography, vegetation, and climate), texture, color, and chemical properties. The spatial distribution of the classes in the RADAMBRASIL maps has been derived from the

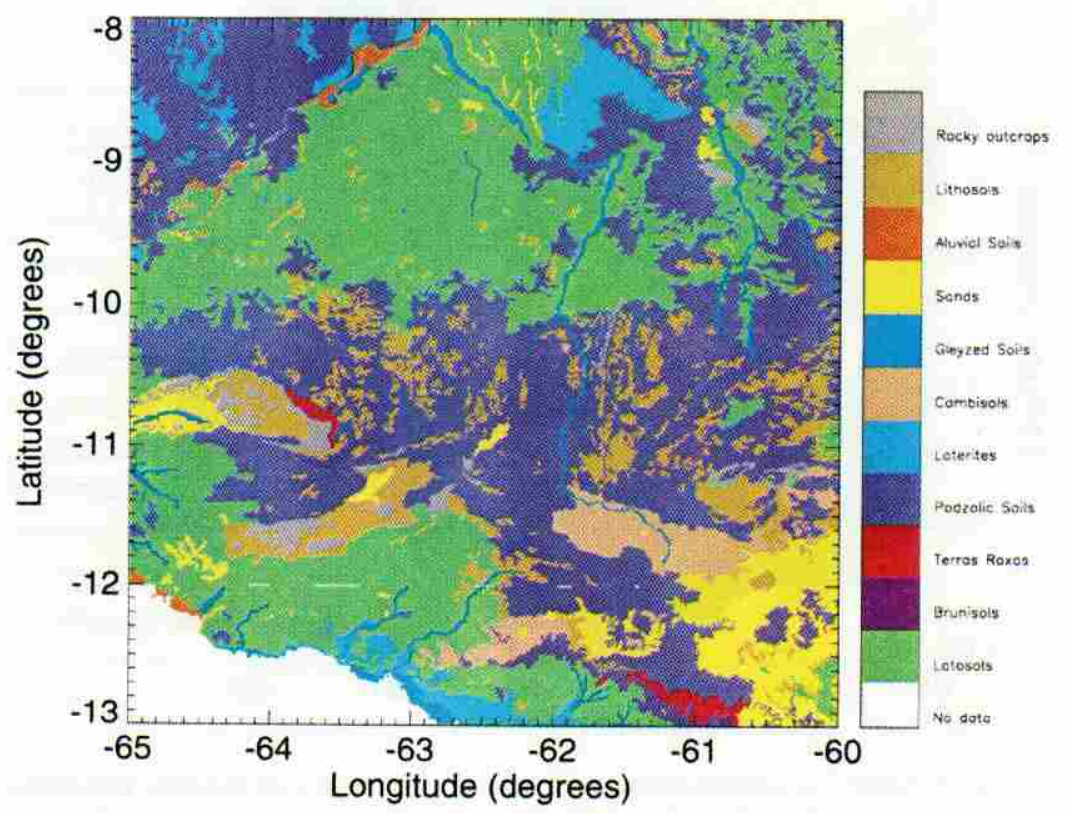

FIG. 4. As in Fig. 3 except for soil. natural vegetation location and from the topography, geology, and geomorphology maps. The allic redyellow podzols and latosols are dominant. Figure 4 presents the soil rasterized image, and again, a reduced number of classes are presented (11 classes). In reality, the map includes 132 subclasses of soil, of which 78 have been fully characterized in the RADAMBRASIL notes using 248 in situ texture profiles.

\section{c. Relief}

A digital elevation model obtained from the source 1:1 000000 maps of IBGE (1979) is presented in Fig. 5 as a rasterized image. As for vegetation and soil class contours, the altitude contour lines have been digitized as vectors and converted into a raster grid. The interpolation process was done both manually by adding points (especially in thalwegs and flat areas) and automatically through an Akima surface-fitting method (PV-WAVE Advantage 1993).

There are marked differences in the relief structure within the studied area. The altitude varies from about 50 to $1100 \mathrm{~m}$. The highest residual plateaus are part of the Pacaás Novos highlands $\left(10^{\circ} 20^{\prime}-11^{\circ} 10^{\prime} \mathrm{S}\right.$, $\left.65^{\circ} 15^{\prime}-63^{\circ} 30^{\prime} \mathrm{W}\right)$. The lowest valley of the area is of the Madeira River in Calama $\left(8^{\circ} 05^{\prime} \mathrm{S}, 62^{\circ} 50^{\prime} \mathrm{W}\right)$.

\section{d. Deforestation assessment}

The forest/nonforest patterns are expected to be responsible for mesoscale circulations and changes in the atmospheric boundary layer structure. The main physical factor for such differences would be the presence of thermal contrasts. Therefore the mapping of these patterns can be obtained from satellite data: either from the viewpoint of the deforestation or thermal properties of the surface. Analysis of high-resolution satellite vegetation indices enables mapping of the deforested areas, and low-resolution infrared data from meteorological geostationary satellites can give access to the regional thermal structure of the area.

\section{1) Meteosat-Derived thermal MAP}

An estimate of the spatial extent of the warmest surfaces of the area was obtained by performing an automatic 
classification of the Meteosat infrared channel data. Four cloudless scenes $(17,19,22$, and 24 August 1994) at 0900 local standard time (LST) were selected. A four-class map of the infrared numerical counts was made by using a k-means method (PV-WAVE Advantage 1993). Figure 6 presents the four classes. Three main warmer areas appear very clearly: 1) the Porto Velho city $\left.\left(8^{\circ} 45^{\prime} \mathrm{S}, 63^{\circ} 50^{\prime} \mathrm{W}\right), 2\right)$ a deforested area close to Ji-Paraná, and 3) a large savannah area at about $150 \mathrm{~km}$ at the north of Reserva Jaru (8 $\left.9^{\circ} \mathrm{S}, 62^{\circ} 10^{\prime}-61^{\circ} \mathrm{W}\right)$. It is interesting to note that the savannahs of the laterite plateaus are similar to deforested areas in terms of surface temperature.

\section{2) LANDSAT-TM DEFORESTATION MAP}

The Landsat data have been processed to obtain a high-resolution $(120 \mathrm{~m})$ forest/nonforest classification. The Landsat pixels have been classified into three categories by using the same k-means method as employed for Meteosat: 1) forested areas (including well-developed regrowth), 2) nonforest areas (including pastures, urban areas, and natural savannahs), and 3) water areas and missing data. The two variables considered in the automatic classification algorithm are normalized values of the greenness vegetation index (GVI) of Crist and Cicone (1984) and the channel 7 numerical count. The GVI is written as

$$
\begin{aligned}
\mathrm{GVI}= & -0.2848 \times \mathrm{TM} 1-0.2435 \times \mathrm{TM} 2-0.5436 \\
& \times \mathrm{TM} 3+0.7243 \times \mathrm{TM} 4+0.0840 \times \mathrm{TM} 5 \\
& -0.1800 \times \mathrm{TM} 7,
\end{aligned}
$$

where TM $i(i=1,7)$ are the numerical counts of the Landsat-TM channels. The six bands of interest in this study cover 450-520 nm (TM1), 520-600 nm (TM2), 630-690 nm (TM3), 760-900 nm (TM4), 1550-1750 nm (TM5), and 2080-2350 nm (TM7).

Maps of the deforestation over the entire $5^{\circ} \times 5^{\circ}$ domain and on a zone of about $120 \mathrm{~km} \times 120 \mathrm{~km}$ are shown in Figs. 7 and 8, respectively. Although the Meteosat scenes have not been geometrically corrected, the patterns shown in Fig. 7 can be compared with the thermal classification of Fig. 6 . It is clear that the warmest areas correspond to nonforest zones. On the other hand, the nonforest areas close to the Guaporé River (at the south of the studied domain) consist of bogs and well-watered areas and do not appear in the warm thermal class.

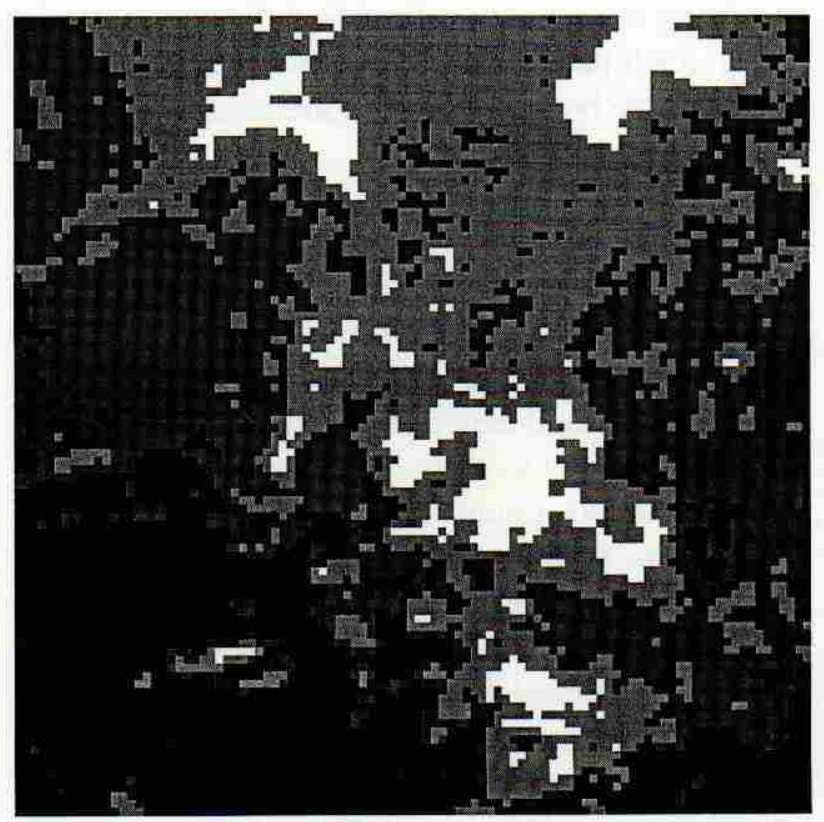

FIG. 6. Thermal classification of a region included in the $8^{\circ}-$ $13^{\circ} \mathrm{S}, 65^{\circ}-60^{\circ} \mathrm{W}$ domain from $100 \times 100$ Meteosat infrared pixels. The four classes have been obtained from four cloudless images acquired at 0900 LST during August 1994. The darkest areas correspond to the lowest infrared radiances. 


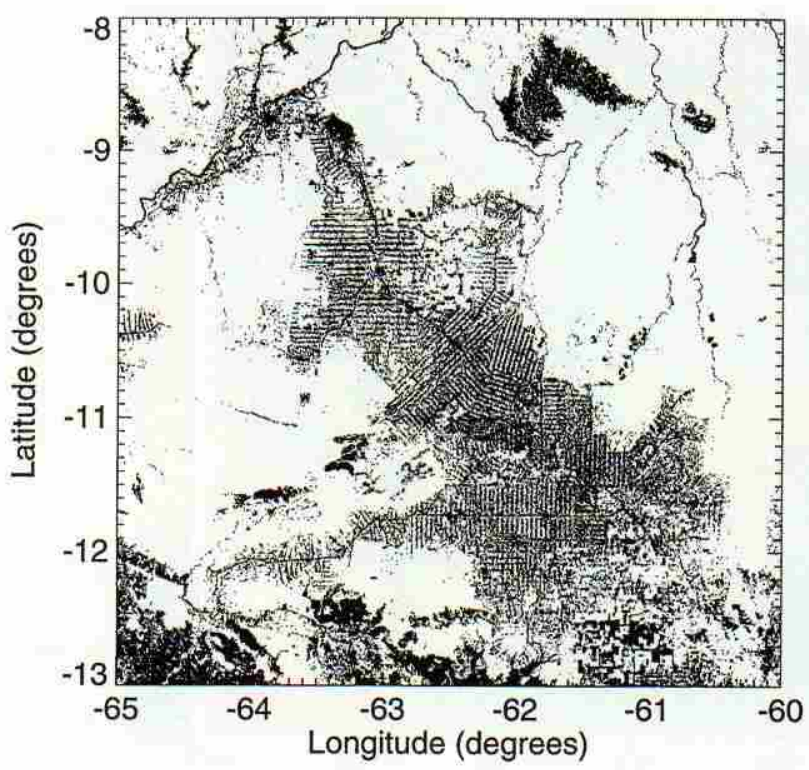

FIG. 7. Landsat-TM-derived forest/nonforest classification of the $8^{\circ}-13^{\circ} \mathrm{S}, 65^{\circ}-60^{\circ} \mathrm{W}$ domain. The dark areas correspond to pasturelands, natural savannahs, bogs, rivers, and lakes. The clear areas are forested zones.

The selected scene of Fig. 8 (28 July 1993) covers the RBLE-3 pasture site and contains (along with forests) pasture fields, water surfaces, and man-made features (roads and urban areas). The two classes presented in Fig. 8 discriminate the deforestation patterns consisting of regularly spaced lines (about one every $4 \mathrm{~km}$ ). Such patterns may have an impact on the dynamics of the boundary layer at mesoscale.

\section{Discussion}

In this study, an attempt is made to extrapolate and derive properties of the land surface in order to simulate the interaction between soil, plants, and air well enough to predict a change in climate that might result from deforestation. The quality of the obtained digital maps is discussed in this section. More often than not, the variables obtained at a given point correspond to unobserved characteristics and their values must be extrapolated and derived from the existing (sometimes qualitative) information. Consequently, it is virtually impossible to quantify the error or the confidence on a given parameter. However, some aspects of the difficulty to map parameters such as elevation, roughness of vegetation, present forest, soil texture, and thermal response to solar heating are considered below.

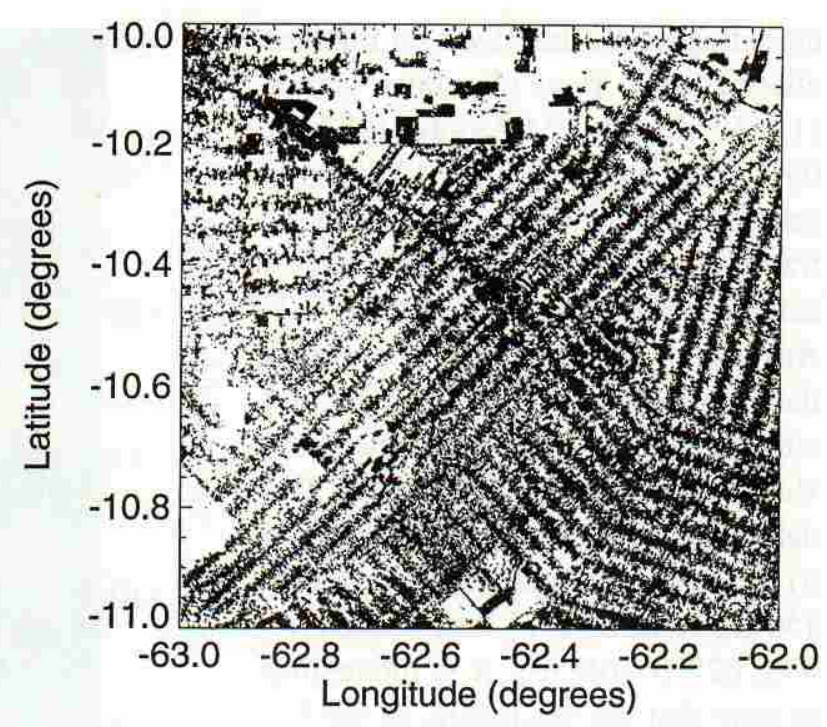

FIG. 8. Zoom of Fig. 7 over the pasture RBLE-3 area of JiParaná (note that the scale is different from the other maps).

In the relief map presented in Fig. 5, the reported altitudes are only estimates of reality. Indeed, the method used to obtain the digital elevation model induces a terracing effect, which appears as marked peaks in the distribution of altitudes (Fig. 9) corresponding to the digitized contour lines of the IBGE maps. The terracing effect is common to all the terrain models obtained from contour line maps (U.S. Department of Commerce-National Oceanic and Atmospheric Administration 1995). Although an interpolation is performed, the prescribed values of the digitized contour lines remain in the terrain model and causes the altitude distribution to be discontinuous. The peaks correspond to multiples of $100 \mathrm{~m}$, which is the interval between adjacent contour lines on the

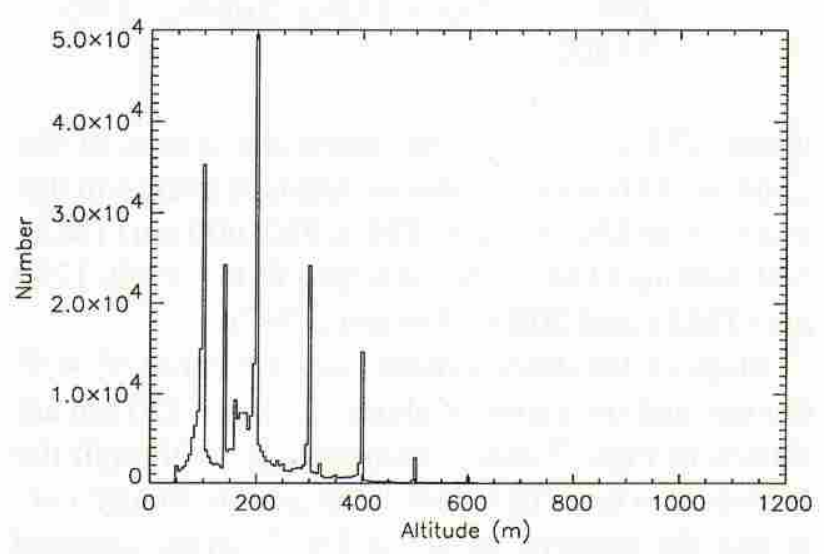

FIG. 9. Histogram of the altitudes reported in the digital elevation model of Fig. 5 . 
source maps. The peak at $140 \mathrm{~m}$ corresponds to the prescribed value of the Bolivian portion of the Guaporé map, for which no data were available at the same scale. This part of Bolivia is a rather flat area with many bogs.

While the relief shown in Fig. 5 can be directly employed in a mesoscale model, the vegetation and soil types (Figs. 3 and 4) constitute qualitative information and must be transformed into physical parameters of the surface scheme. In particular, the interaction of the vegetation with the atmosphere depends on both structural and physiological parameters. The aerodynamic roughness of the canopy is related to the canopy height and stomatal resistance depends on the vegetation type. The hydraulic properties of the soils can be estimated from soil texture and the soil root depth prescribed for transpiration of the vegetation.

It is difficult to estimate the value of these parameters for each vegetation and soil class. However, it may be relevant to extrapolate measured parameter characteristics from the ABRACOS field sites to elements of the digitized maps. Table 1 presents the vegetation and soil structure parameters needed in surface schemes, as measured or estimated for the Rondônia ABRACOS sites of Nossa Senhora Pasture (NSP) and Jaru Reserve Forest (JRF) and for the denser forest near Manaus, the Ducke Reserve Forest (DRF). It appears that the effective soil depth to be used in surface models depends more on the vegetation type (root depth) than on the soil type. For example, although the JRF and NSP sites have similar soils (Eutrofic redyellow podzol and allic red-yellow podzol, respectively), the fact that forest has been replaced by pasture at NSP has very significantly reduced the depth of soil that contributes to transpiration. The leaf area index of the pasture site undergoes important seasonal variations. The lowest value is observed during the dry season (July-August). For all the sites, simple relationships between the canopy height and the aerodynamic parameters (zero plane displacement and roughness length) have been established during ABRACOS (Table 1). These results can be used to draw aerodynamic parameter maps from the canopy height derived from the RADAMBRASIL maps (for natural vegetation) and the Landsat classification (for recently deforested areas).

The RADAMBRASIL maps of natural vegetation and soil type have to be interpreted in terms of natural vegetation height and soil texture. The information contained in the RADAMBRASIL notes has been analyzed in order to obtain a coherent correspondence between the landscape unit classes and these parameters. Figures 10 and 11 present the derived maps of natural vegetation height and soil texture, respectively. In Fig. 11, the proportions of clay (particles diameter $<2 \times 10^{-6} \mathrm{~m}$ ), silt (between $2 \times 10^{-6}$ and $5 \times 10^{-5} \mathrm{~m}$ ), and sand (between $5 \times 10^{-5}$ and $2 \times 10^{-3} \mathrm{~m}$ ) are mapped. A remarkable feature is the relatively low proportion of silt in this area, and the proportion of either clay or sand is predominant. Deriving a soil texture map from a soil classification map is not an easy task. Studying the 248 measured soil profiles, it appears that the texture may vary considerably for a given soil type. To illustrate this variability, Fig. 12 shows different profiles of the proportion of clay corresponding to one podzolic soil class represented in the map. The proportion of clay varies from less than $20 \%$ to more than $60 \%$ for the same soil type. Although some variability would be expected, especially with podzolic soil, the 1:1000 000 scale RADAMBRASIL map will not reproduce the actual

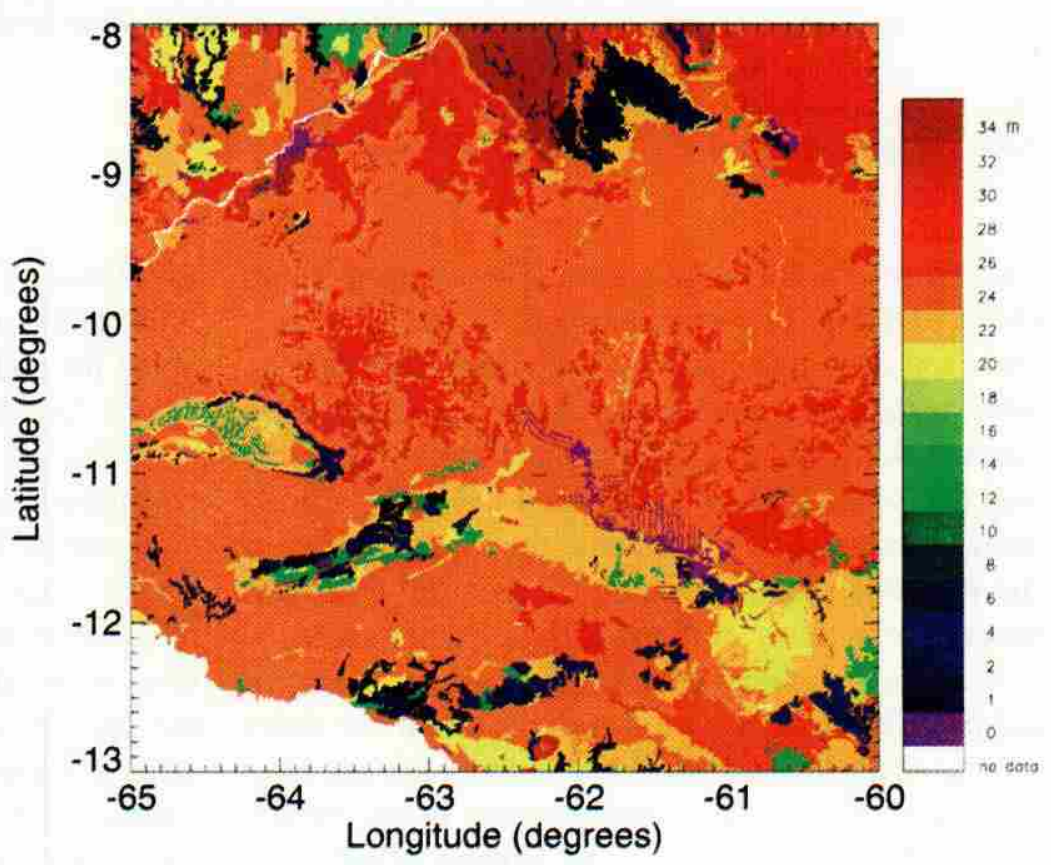

FIG. 10. Digital map of the natural-vegetation height obtained from the vegetation classes (Fig. 3) and the RADAMBRASIL notes (RADAMBRASIL 1978, 1979). 
TABLE 1. Structure parameters of vegetation and soil for forest and pasture sites of the Amazon basin.

\begin{tabular}{|c|c|c|c|c|}
\hline & NSP & JRF & DRF & Source \\
\hline Leaf area index & $1.5-3.9$ & 4.7 & 5.2 & Roberts et al. (1996) \\
\hline Root depth (m) & $<2$ & $>4$ & $>4$ & Wright et al. (1996) \\
\hline Albedo & 0.180 & 0.134 & 0.134 & Culf et al. (1995) \\
\hline Canopy height $h(\mathrm{~m})$ & $0.5-0.6$ & 30 & 35 & Wright et al. (1996) \\
\hline Zero plane displacement $d(\mathrm{~m})$ & $0.71 \times h$ & $0.86 \times h$ & $0.86 \times h$ & $\begin{array}{l}\text { Shuttleworth (1989), } \\
\text { Wright et al. (1992) }\end{array}$ \\
\hline Momentum roughness length $Z_{0}(\mathrm{~m})$ & $0.12 \times h$ & $0.09 \times h$ & $0.06 \times h$ & $\begin{array}{l}\text { Shuttleworth (1989), } \\
\text { Wright et al. (1996) }\end{array}$ \\
\hline Soil bulk density $\left(\mathrm{kg} \mathrm{m}^{-3}\right)$ & 1300 & 1500 & 1100 & Wright et al. (1996) \\
\hline Thermal diffusivity $\left(\mathrm{m}^{2} \mathrm{~s}^{-1}\right)$ & $1.45 \times 10^{-6}$ & - & - & Santos-Alvalá et al. (1996) \\
\hline \multicolumn{5}{|l|}{ Forest interception } \\
\hline Canopy capacity (mm) & 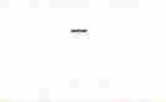 & 0.93 & 0.74 & $\begin{array}{l}\text { Ubarana (1996), } \\
\text { Lloyd et al. (1988) }\end{array}$ \\
\hline Trunk storage (mm) & - & 0.15 & 0.15 & Lloyd et al. (1988) \\
\hline Free throughfall (\%) & - & 3.1 & 8.0 & $\begin{array}{l}\text { Ubarana (1996), } \\
\text { Lloyd et al. (1988) }\end{array}$ \\
\hline Proportion of rain to trunks (\%) & - & 3.6 & 3.6 & Lloyd et al. (1988) \\
\hline
\end{tabular}

NSP: Nossa Senhora Pasture.

JRF: Jaru Reserve Forest.

DRF: Ducke Reserve Forest.

variability of soils in the region. The extreme values observed in Fig. 12 could correspond to the inclusion of other soil types that could not been mapped accurately. Also, texture was not the only factor accounted for in the RADAMBRASIL classification. To tackle this problem and obtain the map presented in Fig. 8, a pragmatic solution was to calculate the median value of the vertically averaged texture for each soil type. This process effectively eliminates the extreme values.

It is also important to note that the current empirical parameterizations employed to obtain the water release characteristics from soil texture have not been designed for the soils of the Amazon basin. Wright et al. (1996) and Tomasella and Hodnett (1996) suggest that errors in the description of the surface hydrology may occur due to bias in existing water release functions. The measurements performed during ABRACOS may help to correct such bias. Details about the soil characteristics of the ABRACOS sites can be found in Wright et al. (1996).

In Fig. 11, discontinuities affect the transition between the RADAMBRASIL maps of Porto Velho and Guaporé (at $12^{\circ} \mathrm{S}$ ). This is due to a different classification of the soil types from one map to another. In the case of the vegetation height (Fig. 10), quantitative information is only available in the Guaporé RADAMBRASIL notes, and the vegetation classes differ somewhat from the Porto Velho ones. The extrapolation to the map of Porto Velho could be performed by prescribing a correspondence between the vegetation classes of the two maps, based on a thorough analysis of the RADAMBRASIL notes. It was 
possible to smooth out the differences at the boundary of the two maps.

Another difficulty in describing the present vegetation is the characterization of the secondary vegetation (i.e., the forest regrowths). In the Landsat-derived land cover classification obtained in this study, it was not possible to discriminate distinct classes representing initial, intermediate, and advanced secondary forests. Instead, a simple forest/nonforest classification has been performed. Presumably, the forest and the pasture classes include welldeveloped and young regrowths, respectively. Therefore, the vegetation characteristics that one may prescribe for such and such class may sometimes be improper since regrowth height, albedo, etc., differ from those of both primary forest and pasture (Giambelluca 1996).

Finally, the thermal classification obtained from the Meteosat data (Fig. 6) can be used to verify the ability of a mesoscale model to simulate the surface temperature field. The Meteosat images were taken during RBLE-3. Given the influence of ephemeral patterns of soil moisture (due to recent rainfall for example) on the surface temperature, the thermal classification obtained from these data is a priori representative of this particular period only. However, RBLE- 3 occured at the end of the dry season: since the dry season (June-JulyAugust) is characterized by a very low amount of rainfall water in this part of the Amazon basin [less than $60 \mathrm{~mm}$ for the 3month period, on average; Fisch (1995)], it is reasonable to think that Fig. 6 gives a rather general look of what happens at the end of the dry season. The obvious correspondence between the warm areas and the deforested zones confirms this hypothesis.

The set of digital maps resulting from this work represents the currently available information about the surface structure of

FIG. 11. Soil texture maps (percentage of clay, silt, and sand) obtained from the soil map presented in Fig. 4. The values employed for each soil classes are medians of the vertically averaged in situ profiles of RADAMBRASIL $(1978,1979)$.
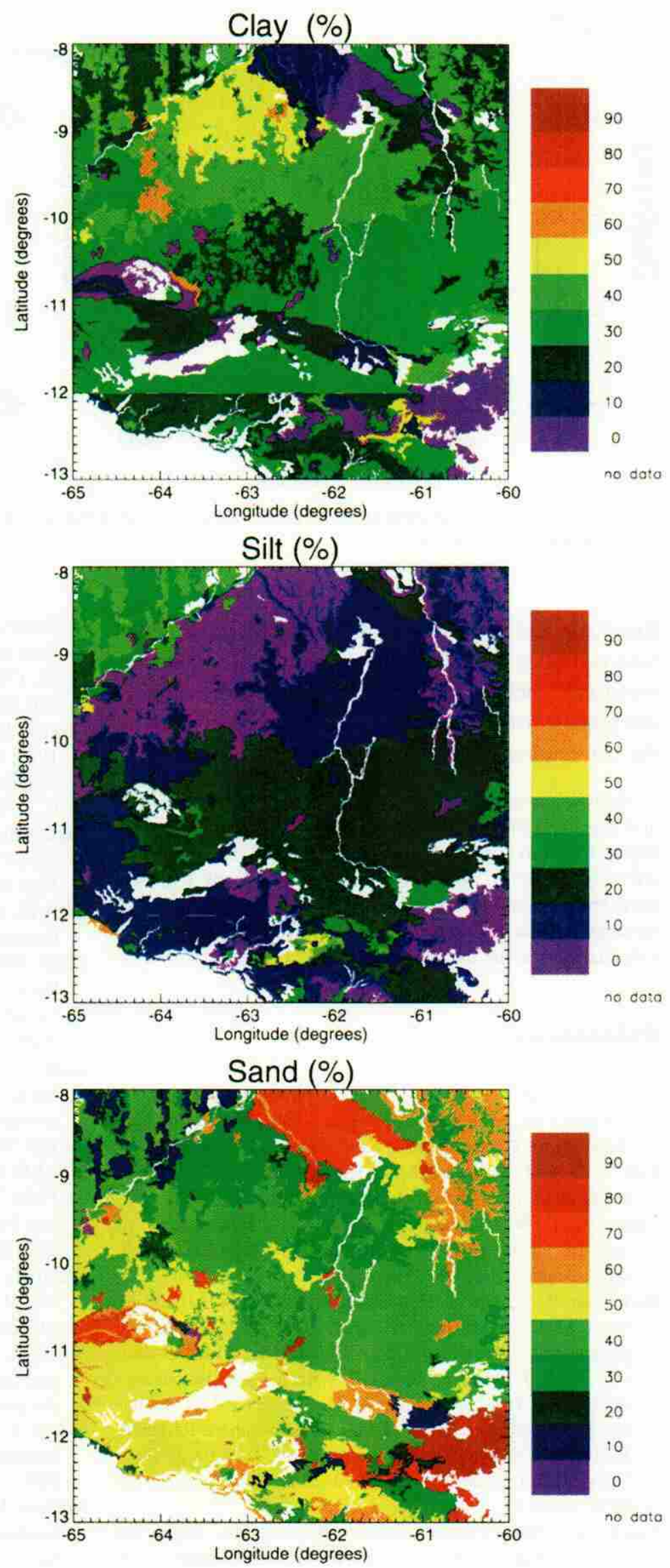

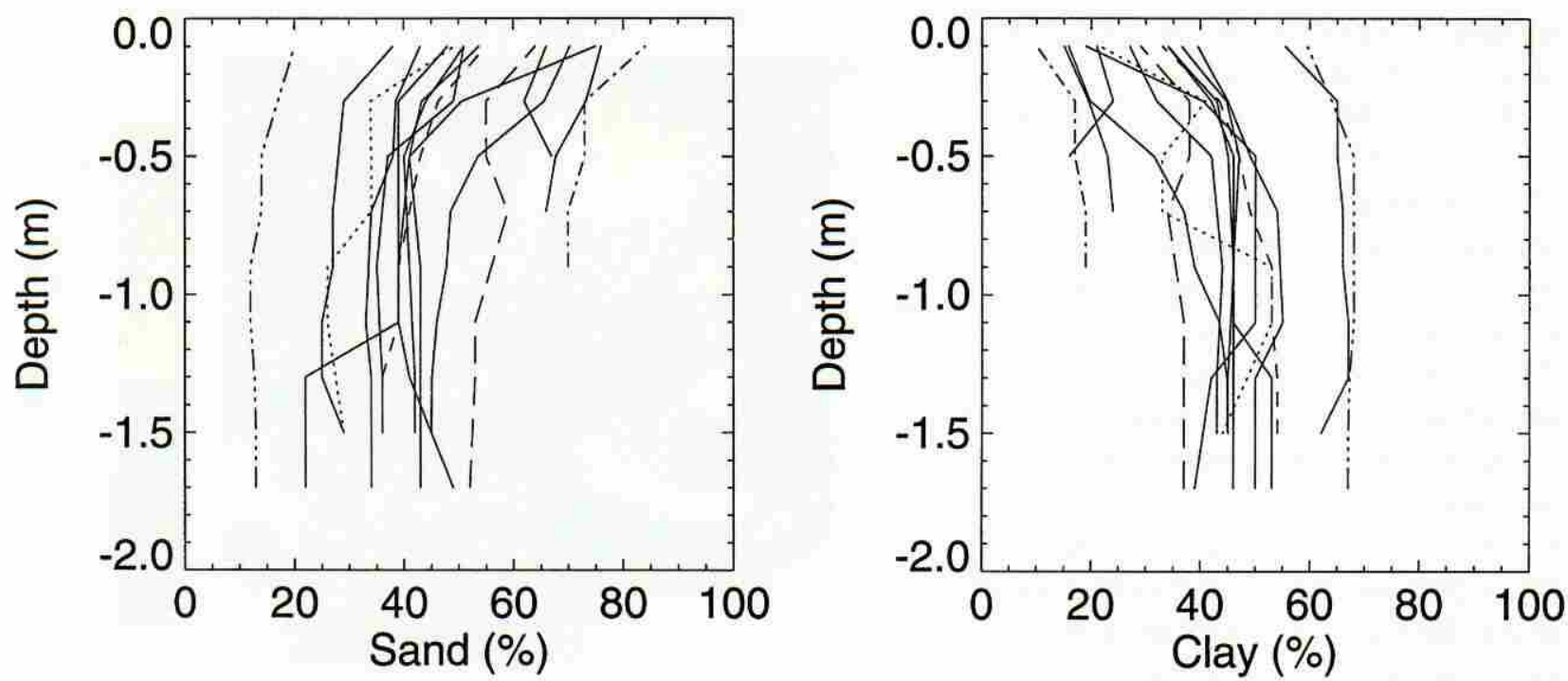

FIG. 12. Clay and sand proportion as measured over a 2-m depth for an allic red-yellow podzolic soil at 15 different places (RADAMBRASIL 1978, 1979).

Rondônia, either natural or recently modified by human activities. This database can serve as a basis for mesoscale meteorological modeling and is available (by request from the corresponding author) for use by the community.

Acknowledgments. This work was performed in the framework of a research program (CABARE) supported by the European Union (CEC Environment Program Project PL-931938, Contract EV5V-CT94-0456). The authors would like to thank INPE for providing the satellite data, the staff of IBGE in Rio de Janeiro for supplying the printed maps, and Mr. J. Chaigneau for techni$\mathrm{cal}$ assistance during the digitizing process.

\section{References}

Crist, E. P., and R. C. Cicone, 1984: A physically-based transformation of thematic mapper data-The TM tasseled cap. IEEE Trans. Geosci. Remote Sens., GE-22, 256-263.

Culf, A. D., G. F. Fisch, and M. G. Hodnett, 1995: The albedo of Amazonian forest and ranch land. J. Climate, 8, 1544.

Cutrim, E., D. W. Martin, and R. Rabin, 1995: Enhancement of cumulus clouds over deforested lands in Amazonia. Bull. Amer. Meteor. Soc., 76, 1801-1805.

Dickinson, R. E., and A. Henderson-Sellers, 1988: Modelling tropical deforestation: A study of GCM land-surface parameterizations. Quart. J. Roy. Meteor. Soc., 114, 439-462.

,-- P. J. Kennedy, and M. F. Wilson, 1986: BiosphereAtmosphere Transfer Scheme (BATS) for the NCAR Community Climate Model. National Center for Atmospheric Research, Tech. Note NCAR/TN-275+STR, $69 \mathrm{pp}$. [Available from NCAR, Information Services, P.O. Box 3000, Boulder, Co 80307-3000.]

Fisch, G., 1995: Camada Limite Amazônica: Aspectos observacionais e de modelagem (Amazonian boundary layer:
Observations and modeling). Ph.D. dissertation, Instituto Nacional de Pesquisas Espaciais, São José dos Campos, Brazil, 170 pp. [Available from INPE/DED, CP515, CEP 12201970 São José dos Campos, SP - Brazil.]

Gash, J. H. C., C. A. Nobre, J. M. Roberts, and R. L. Victoria, 1996: An overview of ABRACOS.Amazon Deforestation and Climate, J. H. C. Gash, C. A. Nobre, J. M. Roberts, and R. L. Victoria, Eds., John Wiley and Sons, 1-14.

Giambelluca, T. W., and A. Henderson-Sellers, Eds., 1996: Climate Change: Developing Southern Hemisphere Perspectives. John Wiley and Sons, 293-318.

GRASS, 1995: Geographic Resources Analysis Support System. Environmental Division of the U.S. Army.

IBGE, 1979: International map of the world on the millionth scale, Porto Velho (SC-20), Guaporé (SD-20), Rio de Janeiro. [Available from IBGE/CDDI, Rua General Canabarro, 666, 20271-201 Maracanã, Rio de Janiero - RJ, Brazil.]

Lean, J., and P. R. Rowntree, 1993: A GCM simulation of the impact of Amazonian deforestation on climate using an improved canopy representation. Quart. J. Roy. Meteor. Soc., 119, 509-530.

Lloyd, C. R., J. H. C. Gash, W. J. Shuttleworth, and A. O. Marques, 1988: The measurement and modelling of rainfall interception by Amazonian rain forest. Agric. Forest Meteor., 43, 277-294.

Mahfouf, J. F., E. Richard, and P. Mascart, 1987: The influence of soil and vegetation on the development of mesoscale circulations. J. Climate Appl. Meteor., 26, 1483-1495.

Manzi, A. O., and S. Planton, 1994: Implementation of the ISBA parameterization scheme for land surface processes in a GCMAn annual cycle experiment. J. Hydrol., 155, 353-387.

Nobre, C. A., P. J. Sellers, and J. Shukla, 1991: Amazonian deforestation and regional climate change. J. Climate, 4, 957 988.

Noilhan, J., and S. Planton, 1989: A simple parameterization of land surface processes for meteorological models. Mon. Wea. Rev., 117, 536-549. 
_ P. Lacarrère, and P. Bougeault, 1991: An experiment with an advanced surface parameterization in a mesobeta-scale model. Part III: Comparison with the HAPEX-MOBILHY dataset.Mon. Wea. Rev., 119, 2393-2413.

Polcher, J., and K. Laval, 1994: The impact of African and Amazonian deforestation on tropical climate. J. Hydrol., 155, 389-405.

PV-WAVE Advantage, 1993: Visual Numerics, Inc., Houston.

RADAMBRASIL, 1978: Levantamento dos Recursos Naturais. Porto Velho, 16:SC-20, 668 pp. [Available from IBGE/CDDI, Rua General Canabarro, 666, 20271-201 Maracanã, Rio de Janiero - RJ, Brazil.]

- 1979: Levantamento dos Recursos Naturais. Guaporé, 19:SD-20, Rio de Janeiro, 378 pp. [Available from IBGE/CDDI, Rua General Canabarro, 666, 20271-201 Maracanã, Rio de Janiero - RJ, Brazil.]

Roberts, J. M., O. M. R. Cabral, J. P. da Costa, A.-L. C. McWilliam, and T. D. A. Sá, 1996: An overview of the leaf area index and physiological measurements during ABRACOS. Amazon Deforestation and Climate, J. H. C. Gash, C. A. Nobre, J. M. Roberts, and R. L. Victoria, Eds., John Wiley and Sons, 287-306.

Rocha, H. R., C. A. Nobre, J. P. Bonatti, I. R. Wright, and P. J. Sellers, 1996: A vegetation-atmosphere interaction study for Amazonian deforestation using field data and a 'single column' model. Quart. J. Roy. Meteor. Soc., 122, 567-594.

Santos-Alvalá, R. C., R. Gielow, I. R. Wright, and M. G. Hodnett, 1996: Thermal diffusivity of Amazonian soils. Amazon Deforestation and Climate, J. H. C. Gash, C. A. Nobre, J. M. Roberts, and R. L. Victoria, Eds., John Wiley and Sons, 139-150.

Sellers, P. J., Y. Mintz, Y. C. Sud, and A. Dalcher, 1986: A simple biosphere model $(\mathrm{SiB})$ for use within general circulation models. J. Atmos. Sci., 43, 505-531.
Shuttleworth, W. J., 1989: Micrometeorology of temperate and tropical forest. Philos. Trans. Roy. Soc. London, Ser. B, 324, 299-334.

Tomasella, J., and M. G. Hodnett, 1996: Soil hydraulic properties and van Genuchten parameters for an oxisol under pasture in central Amazonia.Amazon Deforestation and Climate, J. H. C. Gash, C. A. Nobre, J. M. Roberts, and R. L. Victoria, Eds., John Wiley and Sons, 101-124.

Ubarana, V., 1996: Observation and modelling of rainfall interception loss in two experimental sites in Amazonian forest. Amazon Deforestation and Climate, J. H. C. Gash, C. A. Nobre, J. M. Roberts, and R. L. Victoria, Eds., John Wiley and Sons, 151-162.

USDA, 1970: Soil taxonomy of the national cooperative soil survey. USDA Soil Conservation Service, Washington DC, 510 pp. [Available from U.S. Dept. of Agriculture, Cooperative State Research, South Building, Washington, DC 20250.]

U.S. Department of Commerce-National Oceanic and Atmospheric Administration, 1995: TerrainBase-Worldwilde digital terrain data CD-ROM release 1.0, documentation manual, Boulder, CO, 168 pp. [Available from NOAA/ National Geophysical Data Center, 325 Broadway, E/GC4, Boulder, CO 80303-3328.]

Wetzel, P. J., and J. T. Chang, 1987: Concerning the relationship between evapotranspiration and soil moisture. J. Climate Appl. Meteor., 26, 18-27.

Wright, I. R., and Coauthors, 1992: Dry season micrometeorology of central Amazonian ranchland. Quart. J. Roy. Meteor. Soc., 118, 1083-1099.

— ization for Amazonia. Amazon Deforestation and Climate, J. H. C. Gash, C. A. Nobre, J. M. Roberts, and R. L. Victoria, Eds., John Wiley and Sons, 473-504. 
Copyright of Bulletin of the American Meteorological Society is the property of American Meteorological Society and its content may not be copied or emailed to multiple sites or posted to a listserv without the copyright holder's express written permission. However, users may print, download, or email articles for individual use. 